\title{
СТАН МИТНОЇ БЕЗПЕКИ УКРАЇНИ ТА ОСОБЛИВОСТІ Ïं ЗАБЕЗПЕЧЕННЯ В УМОВАХ ТРАНСФОРМАЦІї ГЛОБАЛІЗАЦІЙНИХ ПРОЦЕСІВ
}

\section{THE STATE OF CUSTOMS SECURITY OF UKRAINE AND FEATURES OF ITS PROVISION IN THE CONDITIONS OF TRANSFORMATION OF GLOBALIZATION PROCESSES}

\author{
Голинський Юрій Олегович \\ кандидат економічних наук, доцент, \\ Львівський національний університет імені Івана Франка \\ ORCID: https://orcid.org/0000-0003-2724-5027 \\ Віхоть Оксана Сергіївна \\ студентка, \\ Львівський національний університет імені Івана Франка \\ ORCID: https://orcid.org/0000-0002-0806-5787
}

Holynskyi Yuriy, Vikhot Oksana

Ivan Franko National University of Lviv

\begin{abstract}
У науковій статті розглянуто та проаналізовано сучасний стан забезпечення митної безпеки України. Визначено основні індикатори митної безпеки, що характеризують фріскальні та регулюючі інструменти митного регулювання в Україні та оцінено частку митних доходів у податкових надходженнях та загальних надходженнях Державного бюджету України. У роботі досліджено коефіцієнт покриття експорту імпортом. Визначено етапи реалізації митної безпеки в Україні та оцінено результати роботи митних органів у напрямі забезпечення надходжень митних платежів до Державного бюджету України. Проаналізовано динаміку справляння фріскальнозначущих митних платежів в Україні. Досліджено динаміку зовнішнього державного боргу та контрабанди товарів через митний кордон України та встановлено взаємозв'язок між ними. На основі отриманих результатів дослідження зроблені висновки.
\end{abstract}

Ключові слова: митна безпека України, індикатори митної безпеки, етапи реалізації митної безпеки, митні платежі, контрабанда товарів.

В научной статье рассмотрено и проанализировано современное состояние обеспечения таможенной безопасности Украины. Определены основные индикаторы таможенной безопасности, характеризующие фрискальные и регулирующие инструменты таможенного регулирования в Украине и оценена доля таможенных доходов в налоговых поступлениях и общих поступлениях Государственного бюджета Украины. В работе исследован коэфффициент покрытия экспорта импортом. Определены этапы реализации таможенной безопасности в Украине и оценены результаты работы таможенных органов по обеспечению поступлений таможенных платежей в Государственный бюджет Украины. Проанализирована динамика взимания фрискально значимых таможенных платежей в Украине. Исследована динамика внешнего государственного долга и контрабанды товаров через таможенную границу Украины и установлена взаимосвязь между ними. На основе полученных результатов исследования сделаны выводы.

Ключевые слова: таможенная безопасность Украины, индикаторы таможенной безопасности, этапы реализации таможенной безопасности, таможенные платежи, контрабанда товаров.

The scientific article considers and analyzes the current state of customs security of Ukraine. The connection of customs and economic security of the state is investigated. The main goal of customs security of Ukraine is determined. The impact of customs security on the national economy is determined. The main indicators of customs security, which characterize the fiscal and regulatory instruments of customs regulation in Ukraine, are determined and the share of customs revenues in tax revenues and general revenues of the State Budget of Ukraine is estimated. Among them the indicator of the use of the potential of customs taxation, the balance of foreign trade, the effectiveness of customs control in the field of foreign economic activity, the level of customs burden on the econo- 
my, the share of imports in domestic consumption and others. The study covers the coefficient of export coverage by imports, which indicates the degree of protection of domestic producers from imported goods and services. The stages of customs security implementation in Ukraine are determined: formation and approval of customs policy to ensure customs security, formation of a customs regulation system in relation to economic interests and goals of the state, which affect the definition of customs regulation, application of selected methods of regulation and control of goods moving across the border and system monitoring customs regulation. The results of the work of customs authorities in the direction of ensuring the receipt of customs payments to the State Budget of Ukraine are assessed. The dynamics of making fiscally significant customs payments in Ukraine is analyzed. The increase in receipts of customs payments to the state budget of Ukraine is estimated. It is proved that the indicator of the share of customs revenues reflects a significant threat to the customs and economic security of our state. The dynamics of external public debt and smuggling of goods across the customs border of Ukraine is studied. It is established that due to the detection of smuggling at state checkpoints it is possible to cover part of Ukraine's foreign debt. Based on the results of the study, conclusions are drawn.

Keywords: customs security of Ukraine, customs security indicators, stages of customs security implementation, customs payments, smuggling of goods.

Постановка проблеми. Одним із ключових аспектів проблеми глобалізації економіки є забезпечення митної безпеки держави. Митна безпека має безпосередній вплив на національну економіку. Насамперед, це контроль за зовнішньоекономічною діяльністю, який спрямований на захист вітчизняного виробника, боротьба з контрабандою, захист об'єктів інтелектуальності власності. Всі ці мають вирішуватись завдяки посиленню митного контролю, тарифнного та нетарифрного митного регулювання. Сучасний стан забезпечення митної безпеки в Україні $є$ особливо важливим, адже реформа Державної митної служби України спрямована на посилення заходів контролю та збільшення товарообігу у державних пунктах пропуску. Саме тому питання митної безпеки України займає чільне місце у дослідженнях науковців.

Аналіз останніх досліджень та публікацій. Значна кількість науковців присвячували свої роботи митній безпеці держави. Серед таких науковців: Бережнюк І.Г. [1], Крисоватий А.І. [2], Дехтяр Н.А. [3], Дейнека О.В. [3], Мартинюк В.П. [7], Проценко Т. [8] та інші.

Виділення не вирішених раніше частин загальної проблеми. Сучасний стан забезпечення митної безпеки України залежить від багатьох фракторів, та найважливіші з них, це рівень корупційних ризиків посадовими особами щодо контрабанди товарів у митному просторі України та ступінь захисту вітчизняного товаровиробника, адже велика кількість імпортних товарів становить значну та нездорову конкуренцію для українських підприємців.

Мета статті. Метою даної роботи є дослідження сучасного стану забезпечення митної безпеки України, її основних індикаторів та етапів реалізації.

Виклад основного матеріалу. Митна безпека України $€$ однією із складових еко- номічної безпеки держави, саме тому митна безпека - це взаємозв'язок політичних та економічних завдань, що сприяють у реалізації державної митної політики України. Критеріями економічної безпеки визначено такі показники або індикатори оцінки стану економіки, що відображають реальний стан економічної безпеки.

На думку науковців, основними індикаторами митної безпеки $€$ повнота сплати митних платежів і повнота виявлення випадків митних правопорушень. Збитки держави від неповного виконання фрункцій митними органами враховують також збитки від економічної контрабанди та недостовірного декларування. Саме ці збитки варто розглядати як основний індикатор митної безпеки, тому що їхня величина характеризує повноту виконання фрункцій митними органами і стан захищеності митних кордонів. Для оцінювання ж рівня митної безпеки існує індикатор фріскальної ефрективності митної справи, що визначається як різниця між статистичною сумою отриманих платежів та тією сумою, яку потрібно стягнути при повному оподаткуванні всього обсягу зовнішньоторгових операцій. Чим менша така різниця, тим вищий рівень митної безпеки. Порогове значення цього показника можна визначити методом експертних оцінок і аналізу аналогічних даних у зарубіжних країнах. Проте неможна однозначно стверджувати, що такі індикатори системно і повною мірою відображають інтереси держави в митній безпеці [1].

Індикатор використання потенціалу митного оподаткування слід визначати через відношення фрактичних надходжень митних платежів до суми, яку можна стягнути при повному оподаткуванні всього імпорту. Повноту сплати митних платежів потрібно розраховувати із врахуванням показників недостовірного декларування й економічної контрабанди. 

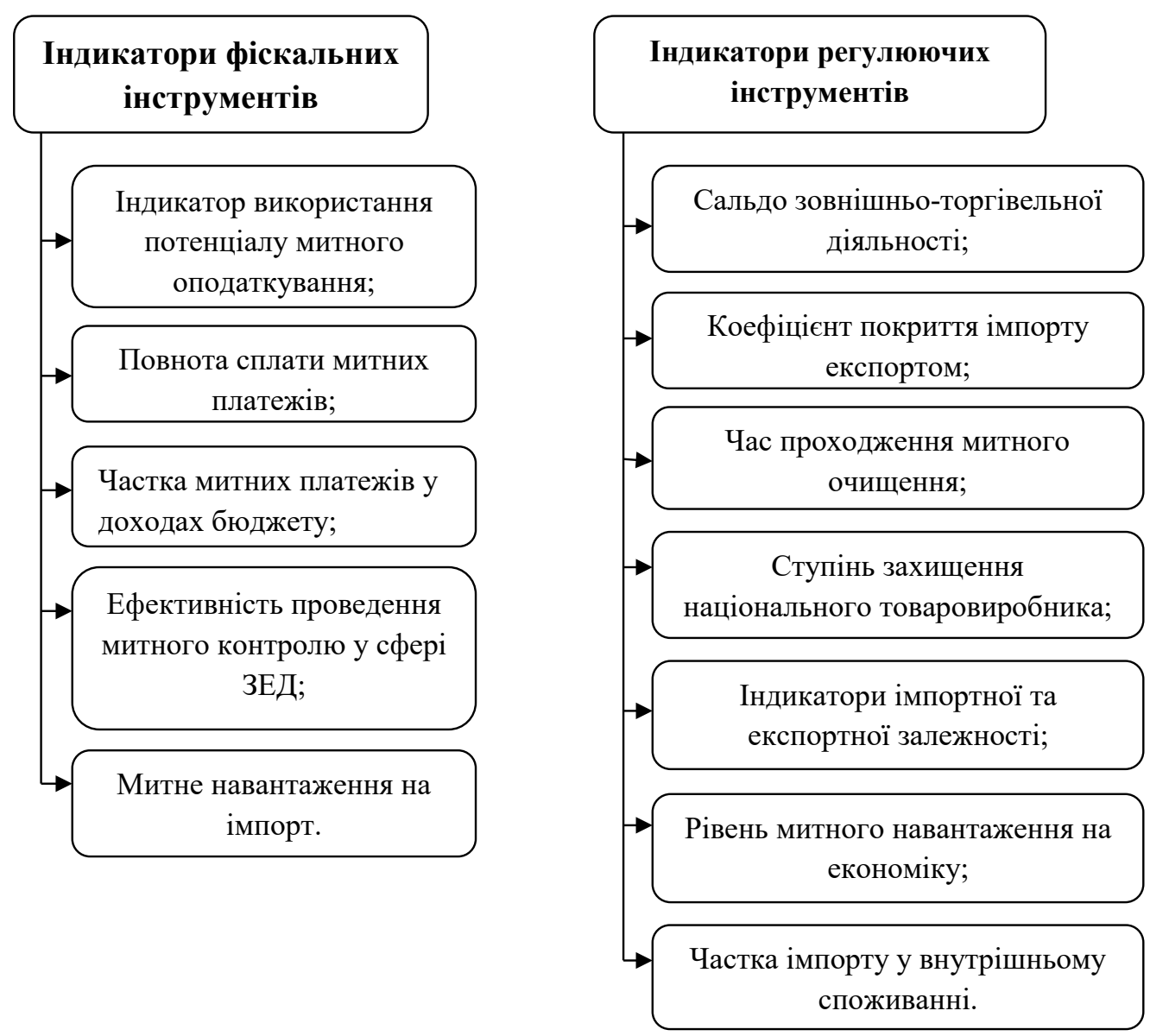

Рис. 1. Індикатори митної безпеки, що характеризують фіскальні та регулюючі інструменти митного регулювання в Україні

Джерело: складено за [2]

Коесріцієнт покриття імпорту експортом визначається як відношення обсягу експорту до загального обсягу імпорту. Індикатори експортної та імпортної залежності розраховуються відповідно як відношення експорту до ВВП і відношення імпорту до ВВП [2].

На рис. 1 класифріковано індикатори митної безпеки у розрізі фріскальних та регулюючих інструментів, які спрямовані на збільшення дохідної частини держбюджету та розвиток міжнародної торгівлі.

Зовнішньоекономічна, в т.ч. митна безпека, прямо пов'язана з митним оподаткуванням. Через диференціацію ставок митного тарифу система митного оподаткування, 3 одного боку, слугує запобіжником контрабанди товарів, нераціональної структури імпорту й експорту, від'ємного сальдо зовнішньої торгівлі, а з іншого - сприяє вільному руху товарів, робочої сили та капіталу, що створює сприятливі умови для розвитку національної економіки завдяки її інтеграції у світовий поділ праці [3].

Для того, щоб визначити ефективність митної політики України у розрізі забезпечення митної безпеки держави доцільно проаналізувати деякі з індикаторів митної безпеки (табл. 1).

Проведений аналіз показників індикаторів митної безпеки України, свідчить про спад

Індикатори митної безпеки України

\begin{tabular}{|l|c|c|c|c|c|c|}
\hline \multicolumn{1}{|c|}{ Індикатори } & $\mathbf{2 0 1 6}$ & $\mathbf{2 0 1 7}$ & $\mathbf{2 0 1 8}$ & $\mathbf{2 0 1 9}$ & $\mathbf{2 0 2 0}$ & $\mathbf{0 1 . 0 9 . 2 0 2 1}$ \\
\hline Частка митних доходів у податках і зборах, \% & 46,9 & 50,4 & 49,0 & 46,7 & 42,6 & 43,9 \\
\hline Частка митних доходів у доходах ДБУ, \% & 38,4 & 39,9 & 39,8 & 37,4 & 33,4 & 36,6 \\
\hline Коефріцієнт покриття експорту імпортом & 0,89 & 0,88 & 0,84 & 0,95 & 0,98 & - \\
\hline
\end{tabular}


частки митних доходів у доходах Державного бюджету України та податкових надходженнях Державного бюджету України у 2020 році. Така від'ємна динаміка, спричинена поширенням інфекційної хвороби COVID-19, закриттям кордонів, веденням карантинних обмежень, а відповідно зменшенням торгівлі та товарообігу між країнами. Суттєву загрозу для митної та економічної безпеки нашої держави відображає індикатор частки митних доходів у всіх надходженнях податків і зборів в Україні: за останніх 5 років його значення було не менше, ніж 42,6\%, а в 2017 р., митні надходження взагалі перевищили надходження від внутрішніх податків та зборів. Щодо коефріцієнту покриття експорту імпортом, показник зростає, що свідчить про розвиток українського виробника та про його успіх на міжнародних ринках.

Ефрективність та надійність митної системи України, завдяки продуктивній діяльності митних органів, є головною метою митної безпеки.

Варто виділити такі етапи реалізації митної безпеки (рис. 2).

В Україні фріскальна складова відіграє вирішальну роль у забезпеченні митної безпеки, оскільки вона спрямована на захист національних економічних інтересів у зовнішньоекономічній і фрінансовій сфрерах одночасно. Виконання митною службою бюджетних завдань залежить від багатьох фракторів: від ефрективності роботи митних органів, розміру бюджетних видатків, що спрямовуються на їхнє утримання, але передусім від державної митної політики, її законодавчого забезпечення та загальноекономічної ситуації в державі [7].

Детальний аналіз питомої ваги митних платежів до дохідної частини Державного бюджету здійснено в табл. 2.

Аналізуючи бюджетні надходження, в Україні можемо простежити, що митні платежі займають велику частку всіх доходів Державного бюджету України. Структура платежів, справляння яких забезпечено державними митними органами, найбільшу частку в надходженні митних платежів займає податок на додану вартість, за станом на 2020 р. на нього припадало 77,8\% усіх надходжень митних платежів та 27,5\% доходів Державного бюджету України.

Варто зауважити, що одним із фракторів, який вплинув на збільшення надходження податку на додатну вартість у період 2015-2018 рр., є запровадження системи електронного адміністрування ПДВ 31 липня 2015 р., яка дала змогу виключити махінації з ПдВ і відповідно збільшити надходження податку до бюджету. Платежі акцизного податку протягом досліджуваного періоду також показали тенденцію до зростання. За період 2016-2021 рр. надходження платежів акцизного податку збільшилися відповідно 3 32 938,9 млн. грн. до 50 470,4 млн. грн.

Сьогодні доволі значною небезпекою $€$ зростання кількості фрактів контрабанди

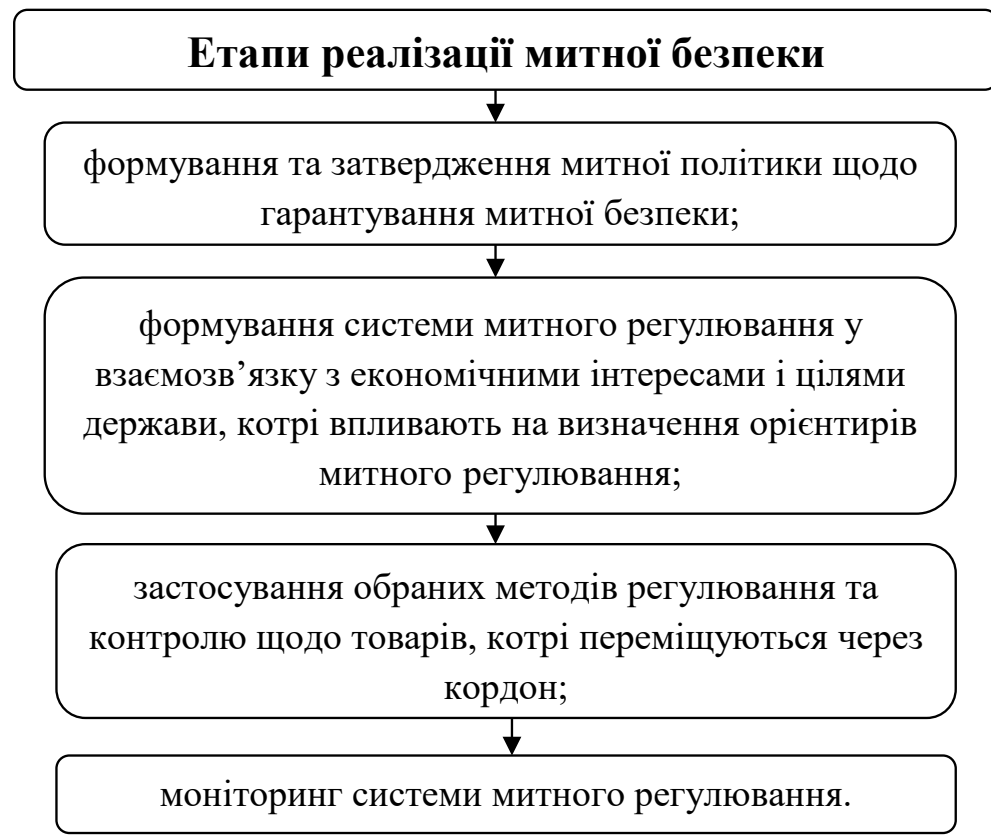

Рис. 2. Етапи реалізації митної безпеки Джерело: складено [6] 
Таблиця 2

Результати роботи митних органів у напрямі забезпечення надходжень митних платежів до Державного бюджету України, 2016-2020 рр., млн. грн.

\begin{tabular}{|l|c|c|c|c|c|}
\hline \multirow{2}{*}{\multicolumn{1}{|c|}{ Найменування показника }} & \multicolumn{5}{c|}{ Роки } \\
\cline { 2 - 6 } & $\mathbf{2 0 1 6}$ & $\mathbf{2 0 1 7}$ & $\mathbf{2 0 1 8}$ & $\mathbf{2 0 1 9}$ & $\mathbf{2 0 2 0}$ \\
\hline Доходи Державного бюджету України & 706509 & 907358 & 1060922 & 998278 & 1076016 \\
\hline Податкові надходження & 598285 & 747214 & 881821 & 799776 & 851115 \\
\hline У. ч., надходження митних платежів: & 236829 & 317060 & 370161 & 373305 & 362419 \\
\hline ПДВ з ввезених на територію України товарів & 181453 & 250530 & 295377 & 289760 & 274113 \\
\hline Акцизний податок (імпорт) & 35006 & 41989 & 47708 & 53460 & 57846 \\
\hline Ввізне мито & 20001 & 23898 & 26560 & 29855 & 30203 \\
\hline Вивізне мито & 369 & 643 & 516 & 230 & 257 \\
\hline Приріст надходжень митних платежів, \% & - & 133,88 & 116,75 & 90,7 & 106,4 \\
\hline $\begin{array}{l}\text { Питома вага митних платежів у загальному } \\
\text { обсязі доходів Державного бюджету України, \% }\end{array}$ & 38,52 & 39,9 & 39,8 & 37,4 & 33,4 \\
\hline
\end{tabular}

Джерело: складено за даними [5]

товарів через митний кордон нашої держави, що є вагомою загрозою митної безпеки України. Контрабанда як явище незаконного перетину товарів через митний кордон України або заниження вартості митних платежів і зборів при перетині товарами митного кордону офріційно в жодному нормативно-правовому акті нашої держави не визначена як окремий правовий термін, але в Митному кодексі України цьому питанню присвячено розділ XVII «Запобігання та протидія контрабанді» [8].

Відсутність статистичної інфрормації не дає можливості визначити ступінь реальних загроз від контрабанди товарів для національної безпеки, бо фрактично неможливо проаналізувати недоотримання державним бюджетом нашої держави коштів у вигляді митних платежів за контрабандні товари. Крім цього, в системі митної служби головний акцент зроблено не на економічній складовій контрабанди, а на її кримінальному змісті, який пов'язаний з перетином митного кордону наркотичними й психотропними речовинами [2].

За допомогою способу зіставлення даних української статистики експорту та імпорту товарів та послуг, та зовнішньої статистики країни-партнера щодо статистики експорту в Україну, можна дослідити обсяг ввезеного контрабандного товару у митний простір України.

За даними статистичної інсрормації зовнішньої торгівлі країн-партнерів України, з яких із

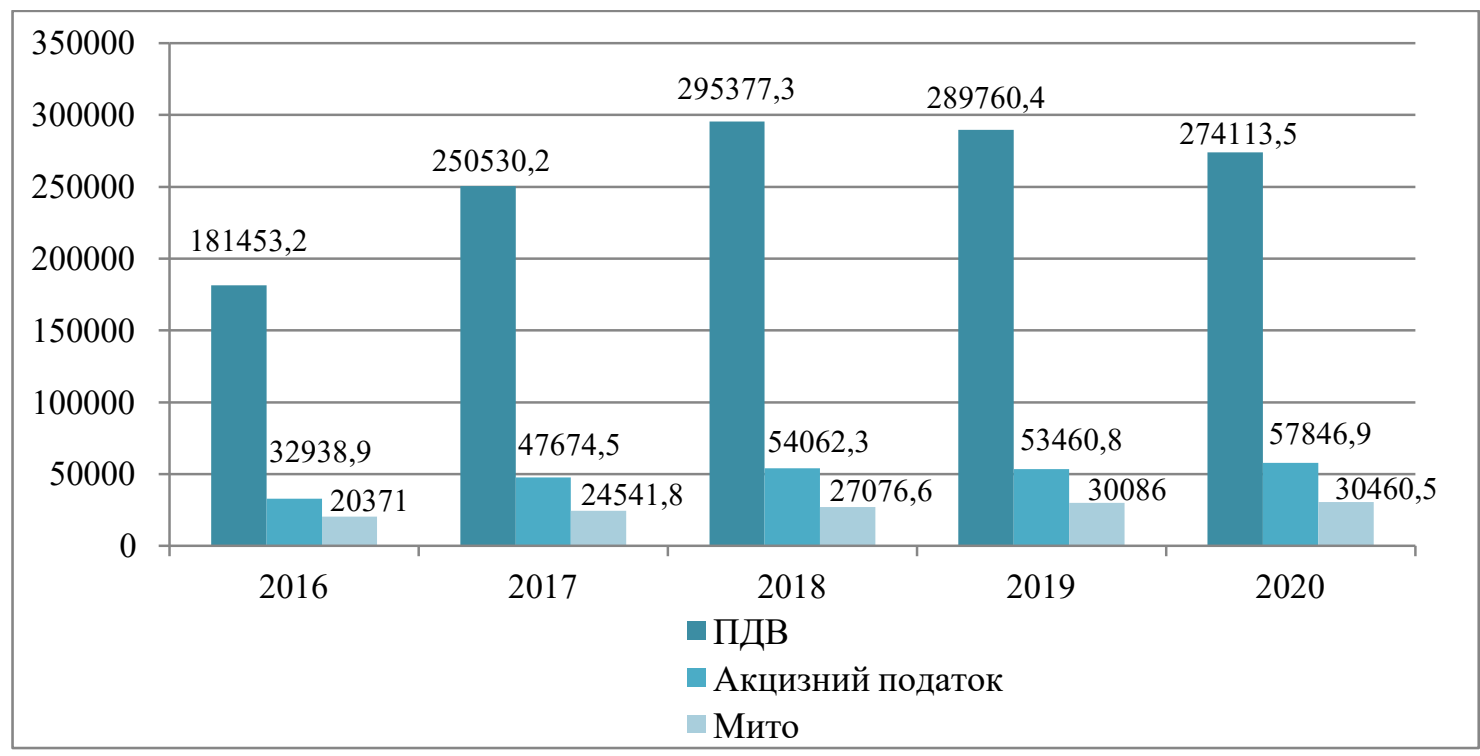

Рис. 3. Динаміка справляння фріскальнозначущих митних платежів в Україні, млн. грн. 2016-2020 рр.

Джерело: складено за даними [5] 


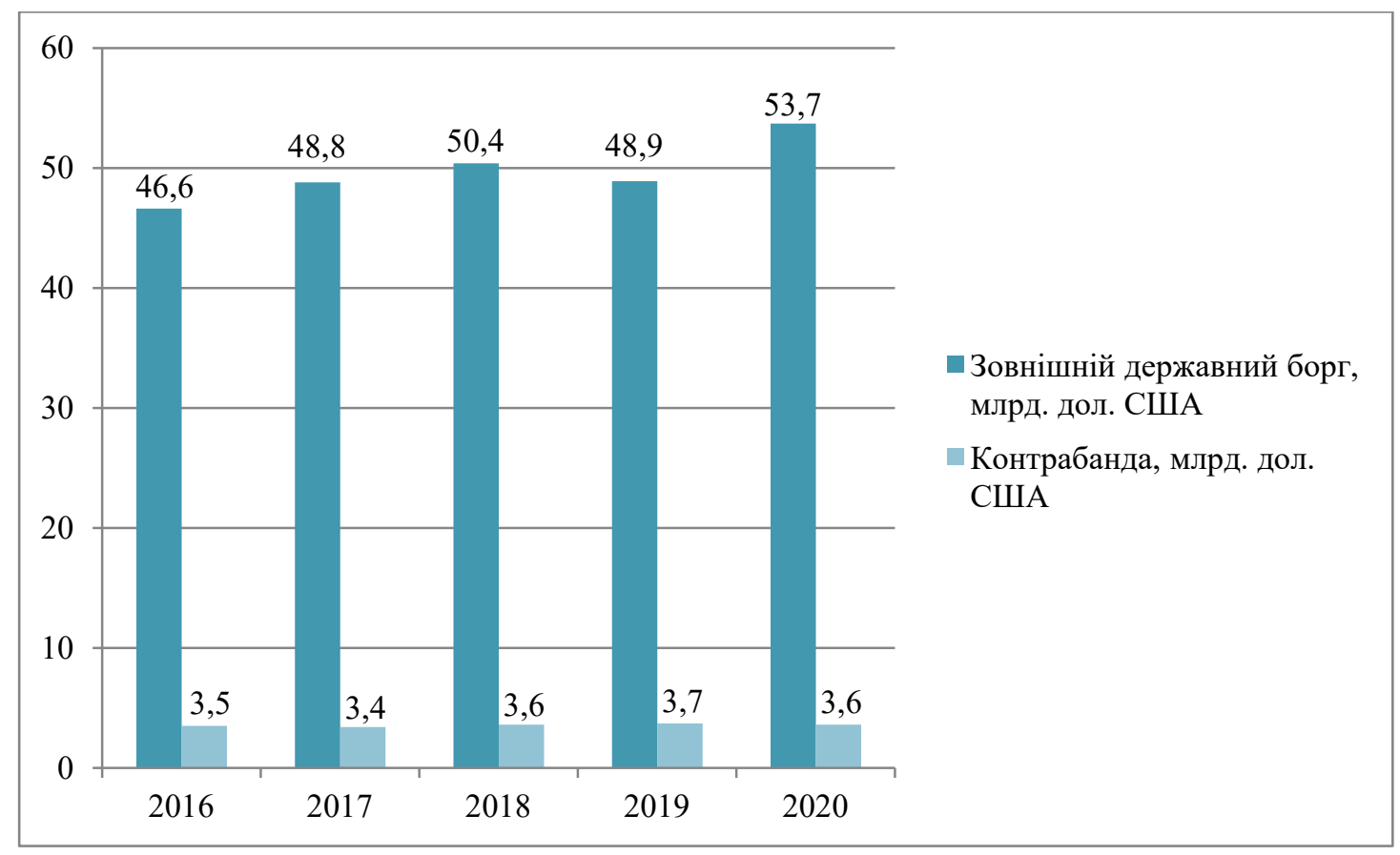

Рис. 4. Динаміка зовнішнього державного боргу та контрабанди товарів через митний кордон України у 2016-2020 рр.

Джерело: складено за даними [2; 5]

високою ймовірністю ввозяться контрабандні товари, визначено ймовірний обсяг тіньової торгівлі (контрабанди) з 2016 р. по 2020 р. включно (рис. 4).

За даними Державної митної служби у 2020 році виявлено 14 тис. порушень митних правил на суму 2,6 млрд грн За результатами розгляду справ судами накладено стягнень (коноріскація товарів та штрафри) на суму майже 1,2 млрд грн і цей показник на 34\% більший за показник 2019 року. За січеньлипень 2021 року співробітники Державної митної служби виявили та припинили понад 10 тис. порушень митних правил на суму майже 1,76 млрд грн [22]. Ці розрахунки свідчать про те, що навіть завдяки митному контролю Державний бюджет України недоотримує значну суму у вигляді податків і митних платежів. Адже за даними статистичної інсрормації країн-партнерів та Державної служби статистики обсяг контрабанди ввезений в Україну протягом аналізованого періоду перевищував обсяг виявленої при митному контролі контрабанди на 30\%. Якщо вважати, що третина від суми контрабанди (приблизний рівень митних платежів та податків) має бути перерахована до державного бюджету, то державний бюджет недоотримує від 1 млрд дол. до 3 млрд. дол. на рік, а це, в перспективі, може використовуватись для погашення зовнішніх запозичень Уряду України.

Боротьба з контрабандою, посилення безпекових фрункцій митниці та персональна відповідальність працівників митниці відносяться до найбільш очікуваних результатів реформи української митниці, адже митна безпека України та боротьба з митними правопорушеннями $\epsilon$ запорукою для розвитку чесного бізнесу в Україні.

Висновки. Дослідження стану митної безпеки в Україні базується на основних індикаторах іï̈ забезпечення: фріскальних та регулюючих інструментах. В розрізі фріскальних інструментів частки митних платежів у доходах Державного бюджету України залишаються в межах норми протягом останніх трьох років, що свідчить про ефективну роботу регулюючих інструментів, а саме захисту національного виробника. Одним з основних завдань митної безпеки, також, залишається контроль за викриттям контрабанди у державних пунктах пропуску, тобто зменшенням обсягу тіньової економіки в України. Саме завдяки якісному забезпечені митної безпеки вітчизняний товаровиробник має змогу конкурувати 3 імпортними товарами, а Державний бюджет наповнюється митними платежами у максимальному обсязі. 


\section{СПИСОК ВИКОРИСТАНИХ ДЖЕРЕЛ:}

1. Бережнюк І. Г. Митне регулювання України: національні та міжнародні аспекти : монографрія. Дніпропетровськ : Акад. митної служби України, 2009. 552 с.

2. Крисоватий А.І. Сучасні виклики забезпечення митної безпеки в Україні : монографія. Тернопіль, 2020. URL: http://dspace.wunu.edu.ua/bitstream/316497/41192/1/моногр.\%20ост.\%20\%281\%29.pdf (дата звернення: 29.09.2021).

3. Дехтяр Н.А., Дейнека О.В. Фінансово-економічна безпека підприємства: сутність та механізм забезпечення : колективна монограсрія. Херсон : Стратегії економічного розвитку: держава, регіон, підприємство, 2015.

4. Державна служба статистики України. URL: http://www.ukrstat.gov.ua (дата звернення: 29.09.2021).

5. Міністерство фрінансів України. URL: https://index.minfin.com.ua/ua/finance/budget/gov/income/2020/ (дата звернення: 26.09.2021).

6. Основні завдання та функції управління організації митного контролю. Державна фіскальна служба України. URL: http://lv.sfs.gov.ua/okremi-storinki/struktura/132906.html (дата звернення: 01.10.2021).

7. Мартинюк В. П. Оцінка фріскального потенціалу митної системи України. Світ фінансів. 2010. № 1. С. 44-55.

8. Проценко Т. Правове регулювання адміністрування податків і митних платежів : дисертація. Київ, 2008. 36 с.

\section{REFERENCES:}

1. Berezhnyuk I.G. (2009) Mytne regulyuvannya Ukrayiny: nacionalni ta mizhnarodni aspekty [Customs regulation of Ukraine: national and international aspects]: monohrafiya [a monograph]. Dnipropetrovsk: Akademiya mytnoyi sluzhby Ukrayiny.

2. Krysovatyj A.I. (2020) Suchasni vyklyky zabezpechennya mytnoyi bezpeky v Ukrayini [Modern challenges of customs security in Ukraine]: monohrafiya [a monograph]. Ternopil. Available at: http://dspace.wunu.edu.ua/ bitstream/316497/41192/1/моногр.\%20ост.\%20\%281\%29.pdf (accessed 29 September 2021).

3. Dextyar N.A., Dejneka O.V. (2015) Finansovo-ekonomichna bezpeka pidpryyemstva: sutnist ta mexanizm zabezpechennya [Financial and economic security of the enterprise: the essence and mechanism of provision]: kolektyvna monohrafiya [a collective monograph]. Kherson: Strategiyi ekonomichnogo rozvytku: derzhava, region, pidpryyemstvo.

4. Derzhavna sluzhba statystyky Ukrayiny [State Statistics Service of Ukraine]. Available at: http://www.ukrstat.gov.ua (accessed 29 September 2021).

5. Ministerstvo finansiv Ukrayiny [Ministry of Finance of Ukraine]. Available at: https://index.minfin.com.ua/ua/ finance/budget/gov/income/2020/ (accessed 26 September 2021).

6. Osnovni zavdannya ta funkciyi upravlinnya organizaciyi mytnogo kontrolyu. Derzhavna fiskalna sluzhba Ukrayiny [The main tasks and management functions of the customs control organization. State Fiscal Service of Ukraine]. Available at: http://lv.sfs.gov.ua/okremi-storinki/struktura/132906.html (accessed 01 October 2021).

7. Martynyuk V.P. (2010) Ocinka fiskalnogo potencialu mytnoyi systemy Ukrayiny [Assessment of the fiscal potential of the customs system of Ukraine]. Svit finansiv, no. 1, pp. 44-55.

8. Procenko T. (2008) Pravove regulyuvannya administruvannya podatkiv i mytnyx platezhiv [Legal regulation of administration of taxes and customs payments]: dysertaciya [a dissertation]. Kyiv. 